\title{
Advanced digital transformations for food security
}

\author{
Elmira Amirova ${ }^{1,{ }^{*},}$ Ilnur Safiullin ${ }^{1}$, Olga Bakhareva $^{1}$, and Amina Sakhbieva ${ }^{2}$ \\ ${ }^{1}$ Kazan State Agrarian University, Kazan, 420015, Russia \\ ${ }^{2}$ Kazan (Volga region) Federal University, 420008, Russia
}

\begin{abstract}
The issues of digital transformation of the modern agricultural economy and the impact of innovative processes on its effective and sustainable functioning in order to ensure food security are analyzed in this article. The key directions for the development of digital production are shown, with the help of which the real prospects for the development of the agrarian sector of the national economy are determined. The current state of digital transformation of the agricultural sector of the economy is analyzed using modeling of the product impact and process innovations on the development of the agricultural economy. The influence of knowledge spreading in the Internet era, the development of network technologies and the use of digital platforms significantly expand the possibilities of both modern network business and business in the agricultural sector of the economy in solving problems related to the implementation of research and development in the field of digital transformation of the agricultural sector of the economy. In the conclusion, it is concluded that the development of rural areas and ensuring of food security in Russia will largely depend on the level of application of information technologies.
\end{abstract}

\section{Introduction}

Almost all spheres of the national economy of Russia are subject to the penetration of progressive technologies that contribute to the integration of digital technologies into the agricultural sector of the economy. Since the end of the last century, the consequences of the use of digital technologies in agriculture have led to innovative changes in soil-agrotechnical and organizational-territorial conditions, which can significantly increase crop yields, animal productivity, reduce production costs and other types of costs, protect the environment, preserve soil fertility [1].

Modernization of all spheres of the national economy is carried out with the implementation of digital technologies which help to discover promising opportunities for effective business and public administration [2,3]. Transforming the digital space, it becomes possible to organize the production and sale of competitive agricultural products, provide high-quality services and get the best administrative solutions. Elements of computer modeling make it possible to reduce the time and funds required for the development and creation of new products and services, starting with the breeding of plants and animals,

\footnotetext{
*Corresponding author: elmira_amirova@mail.ru
} 
ending with complex solutions for digital transformation of both individual agribusiness units and the region as a whole $[4,5]$.

In the modern world, the digital transformation of the agricultural economy is proceeding at a high pace. It has been determined that the number of users of the latest IT solutions grows tenfold annually in the agricultural sector in numerical terms. [6]. Ensuring food independence of our state directly correlates with the pace of implementation of artificial intelligence and advanced solutions in the agricultural sector of the economy. Development and creation of a national digital platform for the management and coordination of all participants in agricultural markets, which still continue to belong to an area with undiscovered potential due to the fact that the quality of communication networks in the Russian Federation does not meet the requirements of the proposed breakthrough strategies for the modernization of agricultural production [7].

The goals of the digitalization processes in the agricultural sector in Russia are the following: achievement of a large increasing in the efficiency of work at enterprises; transformation of state management processes in the field of agricultural economics; ensuring the effectiveness and efficiency of taken decisions; increasing of investments in the Russian economy and export proceeds; development, production control and integration of large amounts of data to create the latest technologies; achieving the maximum profitability of organizations. [8].

Necessary condition for the digital transformation of the agricultural economy is the creation of social institutions in the form of laws, standards, norms and rules. All digital data must be legally and officially enshrined in the international and state acts [9].

Despite all the obviousness of the need for digital transformation, a full-fledged transition of the agricultural economy to management based on the use of progressive digital technologies will be feasible only if this need is used for the entire system of economic relations. Optimization of all structural elements of economic activity is impossible without a developed digital infrastructure $[10,11]$. Consequently, at present, the study of various aspects of the digital agrarian sphere transformation of the economy and the processes of its development is very relevant from a scientific and practical point of view.

Nowadays, digital technologies affect most of the areas. This number also includes agriculture, which is a strategically important area for the Russian Federation. The Ministry of Agriculture of the Russian Federation implements a truly significant project "Digital Agriculture" having the ambitious task to increase the productivity of agricultural enterprises twice by 2024 with the help of digital technologies [12].

\section{Materials and Methods}

The scientific works of Russian scientists and economists on the digital transformation of the economy are the theoretical and methodological basis of this article. [13, 14]. Modern conditions of development predetermine the need to study the issues of digital transformation of the industry, which consists in developing roadmaps for a strategy for the digital transformation of the agrarian economy and adapting the activities of agricultural enterprises in order to form a digital strategy.

The object of the research is the agricultural economy in connection with the infrastructural aspects of its digitalization. Abstract-logical, economic-statistical and graphic research methods were used in the paper. 


\section{Results and Discussion}

The agricultural sector of the economy differs from other sectors of the economy in its conservatism; digital products are not developed here. However, the digital transformation of the industry is necessary in terms of production process management and logistics operations. An example of such actions is the use of digital maps in the cultivation of fields, referred to as "digital farming" technology.

When using this technology, the state of the land and the determination of weather conditions is carried out using regularly uploaded photographs to the monitoring system using satellites, as a result, the artificial intelligence makes technologically important decisions on carrying out the necessary field work. Further, on the basis of mathematical models using Big Data technologies and the use of artificial intelligence in the entire chain of the production cycle, it is possible to forecast of the harvest volume and indicators of demand for finished products.

An idea of the impact of the widespread introduction of innovations in the agricultural sector of the economy on the rate of economic growth can be obtained by analyzing their specifics and features in different periods. Note that the innovations of the second half of the $\mathrm{XX}$ century were mainly of a grocery nature. At this time, one could observe the emergence and introduction into production of space rockets and nuclear power plants, computers of various generations and mobile phones, the improvement of production technology (from the production of chemical fibers and fabrics to the production of aircraft, cars), etc.

Expansion of knowledge in various fields made it possible to develop the current agricultural production and constantly produce better products that acted as competitive goods and stimulated production, increasing of production volumes, providing increase of income and profits of private business and growth of the economy of different countries and the globe as a whole.

The main feature of modern process innovations is that their use in the agricultural business primarily provides a reduction or savings in costs for a particular type of activity, allows you to process large amounts of information, transmitting them over long distances in real time. But process innovation does not necessarily lead to the growth and expansion of output in every such business, and therefore is not a direct and immediate factor of GDP growth. Process innovations provide network businesses with the ability to distribute and redistribute information, provide services of an intangible nature that do not create cost. In this sense, they can lead to a reduction or slowdown in economic growth, expressed by the rate of GDP growth. The relationship of product and process innovations with the development of the economy is shown in the figure $1[8,18-20]$. 


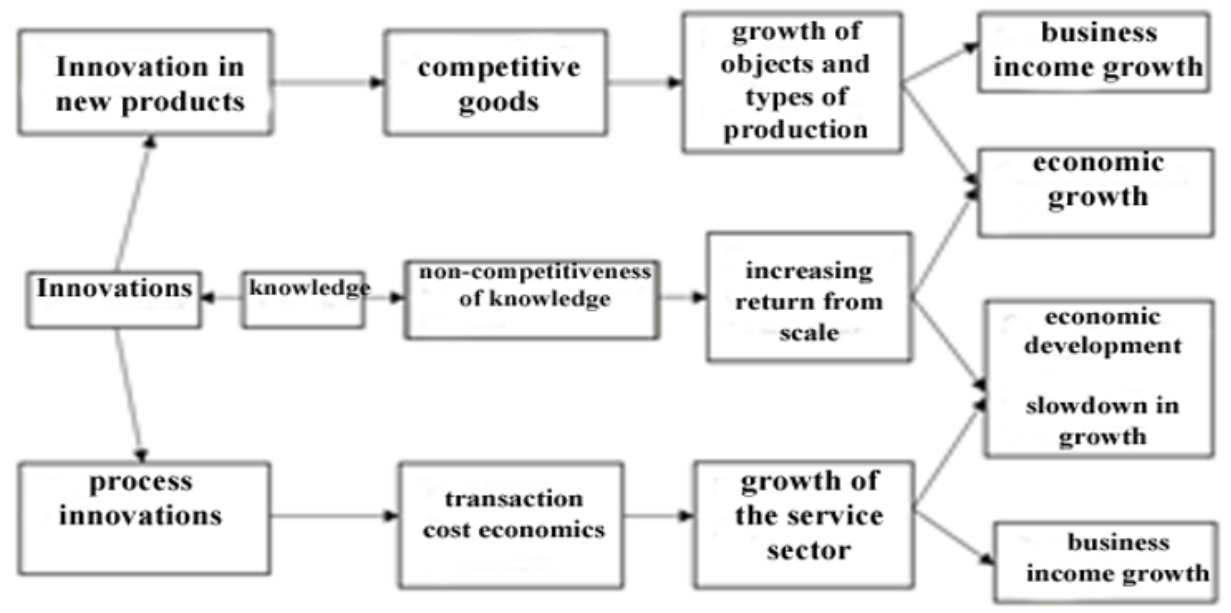

Fig. 1. Impact of product and process innovations on the economic development.

It's necessary to keep in mind that at present the product innovations continue to develop such as robotics in the agricultural sector, 3D printers, new materials, digital platforms, etc. Such developments require significant capital expenditures, the use of highly qualified specialists, significant investments associated with the production of goods and their promotion to the market. The creation of competitive goods can still serve as a definite factor in economic growth. E-commerce, cloud technologies, Internet services are developing at an increasing pace since they often do not imply large capital investments.

In accordance with the Decree of the President of the Russian Federation dated May 7, 2018 No. 204 "On national goals and strategic objectives of the development of the Russian Federation for the period up to 2024", a national program "Digital economy of the Russian Federation" has been formed. One of the objectives of the program is to create a system of legal regulation of the digital economy based on a flexible approach in each area. The implementation of this task is dedicated to the federal project "Normative Regulation of the Digital Environment", which is supervised by the Ministry of Economic Development of the Russian Federation [9].

The following key directions for the development of digital production are distinguished: the formation of technological groundwork [15, 21-23] and research competencies; personnel and education [16, 17]; normative regulation; information security; information infrastructure.

Now the use of information technology in the agricultural sector involves the use of not only computers. Digital technologies make it possible to control the full cycle of both livestock and crop production. So modern devices measure and then provide the parameters of the local climate, soil, plants, etc. All these data from various types of technical means are analyzed by special programs. Online applications, as well as mobile applications, help agronomists and farmers to calculate the fertilization schedule, forecast the harvest, determine the best time for sowing and harvesting, etc.

Modern technologies in the field of agriculture for quite a long time have been actively using in such countries as Europe, Canada and the United States. The demand from domestic farmers for modern digital technologies is increasing, even though they are far from the indicators of the above countries. If you rely on the opinions of experts, then it is the digitalization process that will help make a powerful leap in the development of the national agro-industrial complex.

The main goal of the project for the digital transformation of agriculture, implemented by the Ministry of Agriculture, is the digital transformation of the agricultural sector of the 
economy by introducing platform solutions and digital technologies into this industry in order to achieve an increase in the efficiency of the functioning of digital enterprises in the agricultural sector. $[14,15]$. The initial step of this project was the creation of a national platform - Digital Agriculture. The order regulating the formation of the platform was issued back in February last year. Rostec takes an active part in the transition of the country's agricultural industry to digital technologies. So, the Ministry of Agriculture of the Russian Federation and the Russian state corporation in April 2020 signed an agreement on cooperation in the field of implementation of digital technologies in the agro-industrial complex.

\section{Conclusion}

Thus, the current state of digital transformation of the agrarian sector of the economy has been analyzed using modeling the impact of product and process innovations on the development of the agrarian economy. The impact of the dissemination of knowledge in the Internet era, the development of network technologies and the use of digital platforms significantly expand the possibilities of both modern network business and business in the agricultural sector of the economy in solving problems related to the implementation of research and development in the field of digital transformation of the agricultural sector of the economy in order to provide food security of the country. Summing up, it is important to note that the use of digitalization in agriculture is still in the early stages of formation. The development of agricultural territories will largely depend on the level of application of information technologies. The basic directions of the digitalization process in the future should be the use of smart combines, tractors, unmanned aerial vehicles and other equipment, the development of various services and, of course, distance learning for workers. It is also important to note that it is necessary to properly implement state support for the agricultural sector of the economy, since the uncontrolled introduction of digitalization can ultimately lead to negative consequences for local agricultural producers, due to increasing of imports on the market.

\section{References}

1. E.F. Amirova, Bulletin of Kazan State Agrarian University, 13(1(48)), 147-151 (2018)

2. A. Zakirova, G. Klychova, O. Doroshina, et al., E3S Web of Conferences: 2018 International Science Conference on Business Technologies for Sustainable Urban Development, SPbWOSCE 2018, St. Petersburg (2018)

3. O.V. Kirillova, E.F. Amirova, M.G. Kuznetsov, G.A. Valeeva, G.P. Zakharova, Innovative $\mathrm{d}$ irections of agricultural development aimed at ensuring food security in Russia, BIO Web of Conferences, 00068 (2020)

4. E.F. Amirova, O.V. Kirillova, M.G. Kuznetsov, Sh.M. Gazetdinov, Internet of things as a digital tool for the development of agricultural economy, BIO Web of Conferences, 00050 (2020)

5. Sh.M. Gazetdinov, M.Kh. Gazetdinov, O.S. Semicheva, F.F. Gatina, Reserves for improving the efficiency of integrated formations, BIO Web of Conferences, 00026 (2020)

6. O.V. Bakhareva, Journal of Advanced Research in Law and Economics, 10(8(46)), 2262-2270 (2019)

7. M.S. Faskhutdinova, E.F. Amirova, I.N. Safiullin, L.G. Ibragimov, Human resources in the context of digitalization of agriculture, BIO Web of Conferences, 27, 00020 (2020) 
8. S.S. Vinokurov, P.A. Guryanov, Spatial Economics, 4, 93-111 (2016)

9. E.F. Amirova, M.G. Kuznetsov, E.Khakimova, A.Tolmacheva, Integrated development of digital agribusiness platform to support import substitution of food products, BIO Web of Conferences, 27, 00055 (2020)

10. A.L. Zolkin, A.N.Losev, D.V.Gridina, T.G.Aygumov, Research of problems of computer networks expert systems IOP Conference Series: Materials Science and Engineering, 1047(1), 012106 (2021)

11. A. Zakirova, G. Klychova, G., Ostaev et al, Organizational and methodological approach to managing financial flows of agricultural enterprises, E3S Web of Conferences, 164, 10009 (2020)

12. A.K. Subaeva, M.M. Nizamutdinov, L.M. Mavlieva, M.N. Kalimullin, BIO Web of Conferences, International Scientific-Practical Conference "Agriculture and Food Security: Technology, Innovation, Markets, Human Resources” (FIES 2019), 00226 (2020)

13. A.K. Subaeva, M.M. Nizamutdinov, L.M. Mavlieva, BIO Web of Conferences. International Scientific-Practical Conference "Agriculture and Food Security: Technology, Innovation, Markets, Human Resources” (FIES 2019), 00178 (2020)

14. A.U. Mentsiev, E.F. Amirova, N.V. Afanasev, Digitalization and mechanization in agriculture industry, IOP Conference Series: Earth and Environmental Science: III International Scientific Conference: AGRITECH-III-2020: Agribusiness, Environmental Engineering and Biotechnologies, Volgograd, Krasnoyarsk, Krasnoyarsk Science and Technology City Hall of the Russian Union of Scientific and Engineering Associations. - Volgograd, Krasnoyarsk: Institute of Physics and IOP Publishing Limited, 32031 (2020)

15. A.U. Mentsiev, A. U. Mentsiev, E. F. Amirova, IoT and mechanization in agriculture: problems, solutions, and prospects, IOP Conference Series: Earth and Environmental Science: III International Scientific Conference: AGRITECH-III-2020: Agribusiness, Environmental Engineering and Biotechnologies, Volgograd, Krasnoyarsk, Krasnoyarsk Science and Technology City Hall of the Russian Union of Scientific and Engineering Associations. - Volgograd, Krasnoyarsk: Institute of Physics and IOP Publishing Limited, 32035 (2020)

16. N.A. Safiullin, G.R.Valieva, D.I. Faizrakhmanov, L.N. Savushkina, Ch.M. Kurakova. Quality assessment of electronic state and municipal services using the example of the ministry of agriculture of the Russian Federation, BIO Web of Conferences, 00143 (2020)

17. V. Timiryanova, K. Grishin, D. Krasnoselskaya, Economies, 8(4), 87 (2020)

18. S. Kosnikov, T. Aygumov, F. Khamkhoeva, D. Krasnoselskaya, Amazonia Investiga, 9(28), 519-527 (2020)

19. K. Yusupov, K. Grishin, V. Timiryanova, D. Krasnoselskaya, Amazonia Investiga, 8(24), 452-463 (2019)

20. A.U. Mentsiev, Z. Gerikhanov, A. Isaev, APITECH-2019 Journal of Physics: Conference Series, 1399, 1-6 (2019)

21. R.V. Fattakhov, M.M. Nizamutdinov, V.V. Oreshnikov, Economy of Region, 15(2), 436-450 (2019)

22. A.V. Shmidt, T.A. Khudyakova, Proceedings of the 26th International Business Information Management Association Conference - Innovation Management and Sustainable Economic Competitive Advantage: From Regional Development to Global Growth, IBIMA 2015, 1617-1625 (2015) 
23. V.V. Zhuravlyov, N.Y. Varkova, T.A. Khudyakova, S.V. Aliukov, Proceedings of the 32nd International Business Information Management Association Conference, IBIMA 2018 - Vision 2020: Sustainable Economic Development and Application of Innovation Management from Regional expansion to Global Growth, 550-561 (2018) 